\title{
Surge potential and drainage-basin characteristics in East Greenland
}

\author{
Hester JiSKOOT, ${ }^{1,2,3^{*}}$ Tavi MURRAY, ${ }^{2}$ Adrian LUCKMAN ${ }^{3}$ \\ ${ }^{1}$ Department of Geography, University of Calgary, Calgary, Alberta T2N 1N4, Canada \\ E-mail: hester.jiskoot@uleth.ca \\ ${ }^{2}$ School of Geography, University of Leeds, Leeds LS2 97T, England \\ ${ }^{3}$ Department of Geography, University of Wales Swansea, Swansea SA2 8PP, Wales
}

\begin{abstract}
We introduce a new glacier inventory of central East Greenland and use the collected data to test proposed theories on surging. The glacier inventory contains 259 glaciers, of which 10 have observed surges and a further 61 are inferred surge-type. The total glaciated area is $5.5 \times 10^{3} \mathrm{~km}^{2}$. The inventory was created from a combination of remote-sensing data and maps, and some 24 glacial and geological inventory parameters were collected for each glacier. A multivariate logistic analysis is used to test which combination of glacial and environmental data is conducive to surging behaviour in East Greenland. Three different models suggest that glaciers with a large complexity, low slope and oriented in a broad arc from northeast to south are most likely to be of surge type. Geological conditions, and hence substrate character, appeared not to be related to surge potential. On the basis of these results and the surge dynamics in this region, we suggest a hydrologically controlled surge mechanism operates in central East Greenland.
\end{abstract}

\section{INTRODUCTION}

Glacier surging is a type of bimodal flow behaviour where decadal periods of quiescence are interspersed with sub-decadal periods of rapid flow. Studies of surging show a spectrum in surge behaviour, where initiation and termination, as well as velocity development and periodicity, can vary greatly from glacier to glacier and between surge cluster regions (e.g. Kamb and others, 1985; Dowdeswell and others, 1991; Murray and others, 2000, 2003; Jiskoot and others, 2001). It is clearly possible that different types of surge behaviour involve different controls on glacier flow. Indeed, theories on surge mechanisms suggest a range of possible controls on surging. Our research is based on the notion that environmental and glacial characteristics that distinguish surge-type from normal glaciers in a glacier population can help to identify boundary conditions for surging, which can serve as benchmark data to test surge theories.

Statistical analysis of surge clusters in Svalbard, Canada and Iceland suggested that specific combinations of glacial, geological and environmental attributes are associated with glacier surging (e.g. Clarke and others, 1986; Jiskoot and others, 2000; Hayes, 2001). In order to elucidate if potential surge controls in East Greenland differ from those found for other surge clusters, we performed statistical glacier population research on the major surge cluster in East Greenland. Since insufficient drainage-basin information was available for the entire region (e.g. Nuttall, 1993; Dwyer, 1995) we have created a new geographic information system (GIS)-

* Present address: Department of Geography, University of Lethbridge, Lethbridge, Alberta T1K 3M4, Canada. based glacier inventory. This paper presents the results of the statistical analysis of the associations between geological and glacial characteristics and surge-type glaciers in central East Greenland. A companion paper by Luckman and others (2003) expands on the typical velocities of glaciers in the inventory, while a paper describing the glacier inventory and its production is presently in preparation.

\section{GENTRAL EAST GREENLAND GLAGIER INVENTORY}

About one-quarter, $0.1 \times 10^{6} \mathrm{~km}^{2}$, of the peripheral area around the Greenland ice sheet is covered with local glaciers (Thomsen and Weidick, 1993). Clusters of surge-type glaciers in Greenland occur in central East Greenland, North and northeast Greenland, central West and southwest Greenland (Weidick, 1988). The only Greenland glacier inventories to date are of West Greenland (Weidick and others, 1992) and Hans Tausen Iskappe, North Greenland (Weidick, 2001). Central East Greenland $\left(67-72^{\circ} \mathrm{N}\right)$ is one of the most poorly mapped regions of Greenland, with limited glaciological research. The region encompasses the area between the Stauninger Alps and Kangerlussuaq (Fig. 1) and was identified by Weidick (1988) as a significant surge cluster, even though only five glaciers to date have been observed to surge (Weidick, 1988; Jiskoot and others, 2001). Surges in this region are known to cause extreme calving events (Jiskoot and others, 2001).

\section{Methods}

Glaciers were delineated using ice-flow and topographic data from 18 interferograms from the 1995 and 1996 European Remote-sensing Satellite 1 and 2 (ERS-1/-2) tandem 


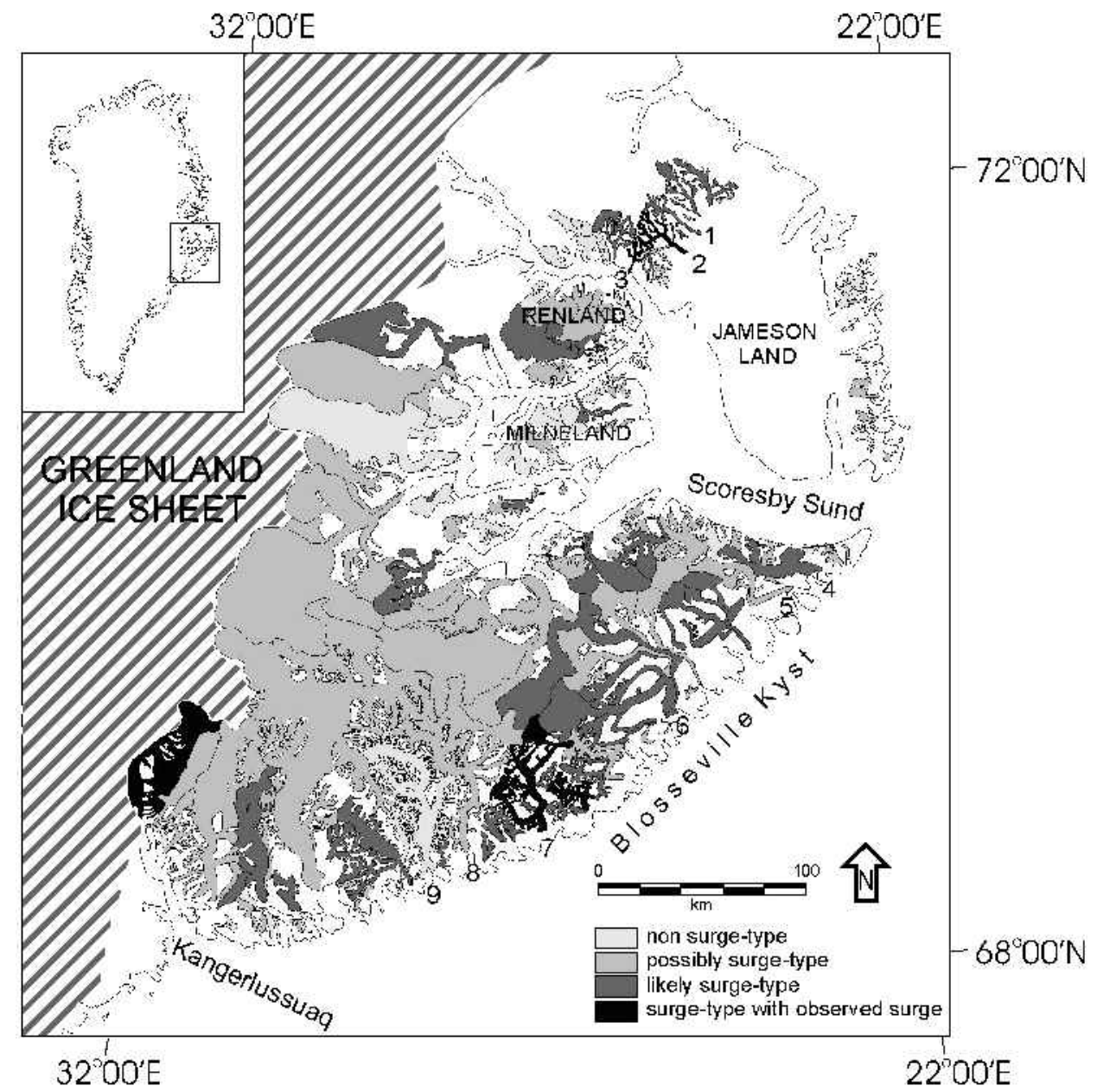

Fig. 1. Glacier inventory map of central East Greenland with general information and surge classification. Numbered glaciers are: 1. Roslingletscher; 2. Bjørnbo Gletscher; 3. Loberen; 4. Torv Gletscher; 5. Steno Bra; 6. Dendrit Gletscher; 7. Sortebre; 8. Borggraven; and 9. Kronborg Gletscher. Hatched area indicates the Greenland ice sheet.

mission. Only glaciers larger than $2 \mathrm{~km}^{2}$ were included in the inventory. In regions where ice-flow rates were too low for interferometric synthetic aperture radar (InSAR) data to yield sufficient information (at ice divides, on plateaux, etc.), where layover occurred or where glaciers were not entirely covered by the ERS images, two Landsat 7 images (from 8 August 1999 and 28 August 2000, with solar elevation angle of $36^{\circ}$ and $29^{\circ}$, respectively), maps at scales $1: 10000$ to $1: 500000$ and aerial photographs from 1981 and 1987 at scales $1: 15000$ and $1: 50000$ were used to delineate glacier drainage basins.

The outlines and centre flowlines of all glaciers were digitized in a GIS, enabling automated extraction of area, length and perimeter data for the glacier inventory. For each glacier, additional glaciological and environmental attributes were collected and assembled in the GIS, providing a baseline digital glacier inventory. Tributaries were only treated as separate units when they displayed flow regimes independent of their trunk glaciers. This was determined through temporal analysis of aerial photographs; for example, tributaries of Sortebræ surged independently of their trunk (Jiskoot and others, 2001). However, for the purpose of our analysis of surging potential we can also incorporate these tributaries with their trunks and treat the entire glacier system as one.

\section{Inventory data and glacier characteristics}

The central East Greenland glacier inventory includes 259 glaciers, with a total glaciated area of $55000 \mathrm{~km}^{2}$. Glacier types include ice caps, valley and outlet glaciers of which many are tidewater-terminating. The inventory data collected for all glaciers are listed in Table 1 . We feel that certain data need additional explanation in the context of their potential control on surging.

(1) "Glacier complexity" is included in our analysis as a measure for possible complex flow and flow obstruction from valley shape. We use the common shape factor for

Table 1. Glacial and environmental data in the glacier inventory

\begin{tabular}{ll}
\hline Continuous variables & Categorical variables \\
\hline Length $(\mathrm{km})$ & Orientation accumulation area \\
Area $\left(\mathrm{km}^{2}\right)$ & Orientation ablation area \\
Perimeter $(\mathrm{km})$ & Curvature \\
Average width $(\mathrm{km})$ & Glacier type \\
Average slope $\left(^{\circ}\right)$ & Glacier shape \\
Complexity & Tributaries \\
Maximum elevation $(\mathrm{m}$ a.s.l. $)$ & Quaternary deposits at margin \\
Minimum elevation $(\mathrm{m}$ a.s.l. $)$ & Geology \\
ELA $(\mathrm{m}$ a.s.l. & Lithology \\
Elevation span $(\mathrm{m})$ & Geological age \\
AAR proxies & Geological boundary type \\
& Geological boundary number \\
& Geological boundary direction \\
\hline
\end{tabular}


sphericity as a quantitative measure of the complexity of the projected outline of a glacier and define glacier complexity, $C$, as:

$$
C=1-\left(\frac{4 \pi A}{P^{2}}\right)
$$

in which $A$ is glacier area $\left(\mathrm{km}^{2}\right)$ and $P$ glacier perimeter $(\mathrm{km})$. This measure allows glaciers of different size to be compared on a scale of zero (least complex) to one (most complex). Glacier complexity in our database ranges from 0.27 to 0.99 . Tidewater-outlet, valley and tidewater-valley glaciers are on average more complex than ice caps and outlet glaciers.

(2) Gurvature in glacier flow direction results in compression (convergence of the velocity field) on the inside of a bend, and extension at the outside bend. These differences in stress regime could also result in different thermomechanical conditions and hydrological regime, and could potentially be a cause of unstable flow. If so, then surge-type glaciers are likely to have a higher degree of curvature than normal glaciers. We define glacier curvature as the degree to which the direction of glacier flow in the ablation area deflects from that in the accumulation area (cf. Hamilton, 1992), and calculated curvature as the difference in octants between the upper and lower parts of each glacier. Hence, we define not only the degree of curvature but also its direction. Gurvature for East Greenland glaciers varies from 3 to +4 octants $\left(135^{\circ}\right.$ anticlockwise to $180^{\circ}$ clockwise).

(3) Equilibrium-line altitudes (ELAs) and two accumulation-area ratio (AAR) proxies were included in the analysis, as mass balance possibly has an effect on surging potential. ELAs were derived from snowlines visible on the Landsat 7 images (8 August 1999 and 28 August 2000) and from the transitions between convex and concave contours on topographic maps at scales 1:100000 to 1:500 000. It can be argued that these measures are not an accurate representation for the long-term ELA, but temporal investigation of the late-summer snowline on Sortebræ (Jiskoot and others, 2001) shows that the year-to-year variability in snowline position is small (within $50 \mathrm{~m}$ vertical). Using these methods, we could only derive ELA data for 231 of the 259 glaciers. AAR proxies were defined as "accumulation-elevation ratio" (AER), the ratio of the elevation difference between the maximum elevation and ELA over the glacier's elevation range, and "AER divided by average surface" slope, in order to compare different glacier types with similar AERs.

(4) Geological conditions have frequently been proposed as a major control on surge potential (e.g. Post, 1969; Hamilton, 1992; Truffer and others, 1999; Jiskoot and others, 2000). Geological data in our inventory were collected from geological maps at scale 1:250 000 and include lithology and type, direction and number of geological boundaries (cf. Jiskoot and others, 2000). About $31 \%$ of the glaciers are underlain by plateau basalts, $30 \%$ by gneisses, $19 \%$ by hyaloclastite basalts, $6 \%$ by granites, $5 \%$ by schists/ quartzites, $4 \%$ by shales, $3 \%$ by migmatites and $2 \%$ by undefined igneous bedrock. About one-third of the glaciers overlie uniform bedrock, one-third overlie one geological boundary and one-third overlie multiple boundaries.

\section{Surge-type glaciers}

Weidick (1988) documented 26 surge-type glaciers in central East Greenland on the basis of surge-related surface morphology visible on aerial photographs and satellite images. Descriptions of individual surge-type glaciers are given for only five glaciers: Løberen (Hendriksen and Watts, 1968), Bjørnbo Gletscher (Rutishauser, 1971), Roslingletscher (Colvill, 1984), Torv Gletscher (Rucklidge, 1966) and Sortebræ (Jiskoot and others, 2001; Murray and others, 2002). Observations for the first four glaciers are based solely on aerialphotograph interpretation of photographs taken $\geq 6$ years apart. Their active phases are estimated to be $5-15$ years, with quiescent phases of 70-150 years, but no repeat surges have been observed. For Sortebræ the observed active phase is $<2$ years, and the observed quiescent phase is 40 50 years (see Jiskoot and others, 2001). Only for Sortebræ have actual surge dynamics been observed, by means of both multi-model photogrammetry (Jiskoot and others, 2001) and intensity tracking using SAR images (Murray and others, 2002). Sortebræ's surge behaviour and dynamics are analogous to typical surge characteristics in Alaska, U.S.A., rather than those in Svalbard.

For this research, an extensive inventory of surge-type glaciers was compiled using aerial-photograph interpretation of photographs taken between 1943 and 1995, Landsat image analysis from the period 1980-2000, as well as surge evidence from maps, published and unpublished reports. Morphological signatures used to determine if a glacier is of surge type include: contorted moraine loops, an abundance of potholes/pits, strandlines, crevasse patterns, depleted surface with moraines standing proud of surface, sheared-off tributaries or tributaries protruding onto trunk. While some morphological surface signatures are diagnostic for surging (e.g. tear-shape elongated moraines), others are not unique to surging behaviour (e.g. heavy crevassing). Consequently, there will always remain uncertainties in the identification and classification of surge-type glaciers without observed surges. It is therefore normal practice in the statistical analysis of surge-type glaciers to assign a surge index, representing the likelihood that a particular glacier is of surge type (Clarke and others, 1986). A surge index is based on the strength of evidence for surge behaviour, ranging from ambiguous morphological evidence to an observed surge. We used a fourcategory surge classification with

(0) 81 non-surge-type glaciers,

(1) 107 possibly surge-type glaciers (with one or two types of surface features indicative of surging behaviour, but that could also be caused by a flow regime other than surging),

(2) 61 likely surge-type glaciers (one or more unequivocal surge-type features: e.g. tear-shape elongated moraines), and

(3) 10 glaciers with an observed surge.

Figure 1 displays the distribution of surge-type glaciers over the region.

STATISTIGAL TESTS TO DISTINGUISH SURGETYPE FROM NORMAL GLACIERS

\section{Technique}

In order to analyze the independent (univariate) and com- 
Table 2. Number of glaciers in each of the three optimal models, and model specifications

\begin{tabular}{|c|c|c|c|c|}
\hline \multirow[t]{2}{*}{ Model name } & \multicolumn{3}{|c|}{ Number of glaciers } & \multirow[b]{2}{*}{ Description } \\
\hline & Total & Surge-type & Normal & \\
\hline FULL & 259 & 71 & 188 & $\begin{array}{l}\text { Full dataset: tributaries treated } \\
\text { separately }\end{array}$ \\
\hline WTRUNK & 212 & 56 & 156 & $\begin{array}{l}\text { All tributaries included into } \\
\text { their trunks }\end{array}$ \\
\hline WELA & 231 & 60 & 171 & $\begin{array}{l}\text { Only glaciers for which ELA } \\
\text { data were available }\end{array}$ \\
\hline
\end{tabular}

bined (multivariate) effects of glacier and environmental characteristics on the incidence of glacier surging in central East Greenland, multivariate logistic regression models or "logit models" were used. This type of statistical analysis has recently proven successful in the analysis of glacier surging in Svalbard (Jiskoot and others, 1998, 2000). Our logit models calculate the log-odds of a binary "event" (1 for "presence" and 0 for "absence" of a surge-type glacier) occurring in a glacier population, using the best fit of a combination of explanatory variables (Table 1), for which no assumptions about statistical distribution need to be made. Our four-category surge index was consequently grouped into a dichotomous surge index with 71 surge-type (cate- gories 2 and 3) and 188 normal glaciers (categories 0 and 1). Logit models are fitted stepwise, starting with a "null model", which only includes an intercept effect (the constant that best fits the average response of the data). The deviance $(D)$ that results from a null model is a baseline against which the improvement of the model fit can be determined for the addition of each explanatory variable that corresponds with the loss of degrees of freedom (DF) through the addition of the variable. Since the reduction in $D$ between separate models can be approximated to have a $\chi^{2}$ distribution, it can be used as an indicator of the significance of each term added to the model. An "optimal model" is reached when further inclusion of any remaining variables no longer results in significant reduction in $D$. The influence of each variable on the surge potential is assessed through the sign and magnitude of the "estimates" (log-odds) (Jiskoot and others, 2000). Interaction between variables is accounted for in the multivariate models: with the inclusion of each of the variables, the association between that term and other variables was also tested. For a complete account of this technique as used for glacier surging, see for example Jiskoot and others $(1998,2000)$.

\section{Model results}

In the univariate logistic models, we tested all variables listed in Table 1 on their individual likelihood of being associated

Table 3. Optimal multivariate models and their null models

\begin{tabular}{|c|c|c|c|c|c|c|c|c|c|c|}
\hline & Variable & Subgroup & Est. & S.E. & Prob. & $D$ & DF & $\Delta D$ & $\Delta \mathrm{DF}$ & $\chi^{2}$ \\
\hline FULL null & Intercept & & -0.97 & 0.14 & 0.27 & 304 & 258 & & & \\
\hline FULL multivariate & $\begin{array}{l}\text { Intercept } \\
\text { Orient. acc. area } \\
\text { Slope } \\
\text { log-span } \\
\text { log-area } \\
\text { log-span.log-area }\end{array}$ & NE-S & $\begin{array}{r}-27.34 \\
1.13 \\
-0.59 \\
4.43 \\
7.90 \\
-1.34\end{array}$ & $\begin{array}{l}7.96 \\
0.38 \\
0.14 \\
1.22 \\
3.63 \\
0.52 \\
\end{array}$ & $\begin{array}{l}0.00 \\
0.75 \\
0.36 \\
0.99 \\
1.00 \\
0.21\end{array}$ & 239 & 253 & 66 & 5 & 11.07 \\
\hline WTRUNK null & Intercept & & -1.03 & 0.16 & 0.26 & 245 & 211 & & & \\
\hline WTRUNK multivariate & $\begin{array}{l}\text { Intercept } \\
\text { Complexity } \\
\text { Slope } \\
\text { Glacier type }\end{array}$ & $\begin{array}{l}\text { Ice cap } \\
\text { Valley } \\
\text { Tidewater outlet } \\
\text { Tidewater valley } \\
\text { NE-S } \\
\text { Palaeo-Mesozoic } \\
\text { Tertiary }\end{array}$ & $\begin{array}{c}-7.11 \\
8.98 \\
-0.51 \\
0.43 \\
1.56 \\
-2.33 \\
-0.43 \\
1.42 \\
3.60 \\
1.09\end{array}$ & $\begin{array}{l}2.12 \\
2.34 \\
0.15 \\
1.36 \\
0.86 \\
0.89 \\
0.87 \\
0.56 \\
1.65 \\
0.52\end{array}$ & $\begin{array}{l}0.00 \\
\mathbf{1 . 0 0} \\
\mathbf{0 . 3 7} \\
0.61 \\
0.83 \\
\mathbf{0 . 0 9} \\
0.39 \\
\mathbf{0 . 8 1} \\
\mathbf{0 . 9 7} \\
\mathbf{0 . 7 5}\end{array}$ & 131 & 202 & 114 & 9 & 16.92 \\
\hline WELA null & Intercept & & -1.05 & 0.15 & 0.26 & 265 & 230 & & & \\
\hline WELA multivariate & $\begin{array}{l}\text { Intercept } \\
\text { Complexity } \\
\text { Slope } \\
\text { Geological age } \\
\text { Orient. acc. area } \\
\text { log-area } \\
\text { log-ELA }\end{array}$ & $\begin{array}{l}\text { Palaeo-Mesozoic } \\
\text { Tertiary } \\
\text { NE-S }\end{array}$ & $\begin{array}{r}-14.56 \\
7.50 \\
-0.30 \\
3.74 \\
1.05 \\
1.29 \\
-1.08 \\
1.40\end{array}$ & $\begin{array}{l}4.00 \\
2.04 \\
0.12 \\
1.47 \\
0.43 \\
0.43 \\
0.47 \\
0.58\end{array}$ & $\begin{array}{l}0.00 \\
1.00 \\
0.43 \\
0.98 \\
0.74 \\
0.78 \\
0.25 \\
0.80\end{array}$ & 179 & 223 & 86 & 7 & 14.07 \\
\hline
\end{tabular}

Notes: The estimates (Est.) are in log-odds and are also displayed as probabilities (Prob.): bold probabilities indicate significant terms. An estimate is significant when it is two times or more its standard error (S.E.). $D$ is deviance, DF degrees of freedom and $\Delta D$ and $\Delta \mathrm{DF}$ reduction in $D$ and DF caused by the multivariate models. Since all $\Delta D$ values are much larger than the critical $\chi^{2}(p=95 \%)$ values, the models are highly significant. The term "log-span.$\log$-area" in the FULL model is an interaction term indicating that small glaciers $\left(<25 \mathrm{~km}^{2}\right)$ with large elevation spans are more likely to surge. 
with surging. All univariate models return the following glacier characteristics associated to surging: high complexity, low surface slope, large length and area, long perimeter and accumulation areas oriented in easterly directions. Geological characteristics associated with surge-type glaciers are plateau basalts and sedimentary bedrock, indicating that softer and more permeable rocks appear conducive to surging. Because ELA data were not available for some glaciers and since tributaries can be regarded as separate units as well as being incorporated into their trunk glacier, we fitted three separate multivariate models (Table 2).

Multivariate models show that some of the variables apparently related to surging in the univariate models are not significantly related to surging when the combined effects of all variables are analyzed. The optimal FULL, WTRUNK and WELA multivariate models (Table 3) all imply that complex glaciers with relatively low slopes and oriented in a broad arc from northeast to south are most likely to surge. Although the optimal FULL model in Table 3 does not include complexity, a model including only complexity and orientation was almost as significant. Hence, the results for slope, complexity and orientation appear robust and suggest that these attributes contain possible controls on surging. However, other attributes are more ambiguous in their relationship to surge potential. In the FULL model, bedrock boundaries with orientations oblique to the glacier flow appear significantly associated with surge-type glaciers. However, the number of glaciers overlying this type of boundary in the other two models is too small to make this parameter statistically significant in these models. Palaeozoic and Tertiary age bedrocks rather than the older Precambrian rocks are associated with surging glaciers in the WTRUNK and WELA models, but have no significant effect in the FULL model. Finally, the optimal WELA model suggests that the probability of surging increases with a rise in ELA, implying a mass-balance control.

\section{Model performance}

By applying the logistic regression equation obtained in the optimal models to each of the glaciers in the database, optimal logit models can be utilized to obtain model fits for each glacier (probability that the glacier is of surge type). The contribution of individual glaciers in the statistical model can then be explored through a residual analysis, in which model fits are compared to the surge indices. Model fits range from 0 to 1 , and glaciers with a fit $\geq 0.6$ are predicted to be of surge type, while glaciers with a fit $<0.4$ are predicted to be normal. Fits in the range $0.4-0.6$ are undetermined. A perfect model would have all normal glaciers fitted as 0 and all surge-type glaciers fitted as 1 . With this residuals method, "outliers" in the data can be isolated, and unusual surge-type and normal glaciers identified. This model performance or "residuals" method has previously proven successful for predicting surging in Svalbard (Jiskoot and others, 2000).

The WTRUNK model performance (Fig. 2) shows that over $60 \%$ of surge-type glaciers and almost $70 \%$ of normal glaciers are fitted well. Seven normal glaciers in the Blosseville Kyst region (including Borggraven, Kronborg Gletscher and Steno Bræ) and one in the Stauninger Alps are predicted to be of surge type; all except Kronborg were classified as type 1 (possibly surge type). Thus, the model results could be used as additional evidence for assessing the likelihood

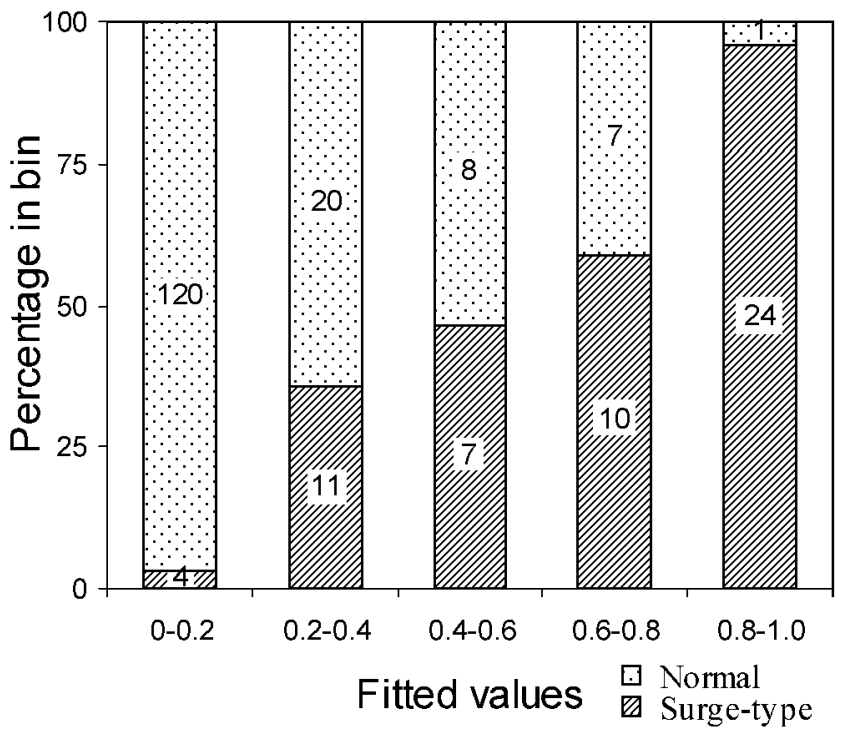

\begin{abstract}
Fig. 2. The model performance for the WTRUNK model shown as fraction of glaciers predicted in each of the five bins of fitted values. Glaciers with high fitted values $(>0.6)$ are predicted to be of surge type, while glaciers with low fitted values $(<0.4)$ are predicted to be normal (non-surge type). The numbers in the bars are the numbers of normal and surge-type glaciers in each bin. The figure shows that there is a direct relationship between increasing fit and fraction of surge-type glaciers.
\end{abstract}

that a glacier is of surge type. The four surge-type glaciers with a fit $<0.2$ are former tributaries of surge-type trunks or share their accumulation areas with other surge-type glaciers and might therefore be triggered by surges of other glaciers rather than have their own surge regime and controls (cf. Clarke and others, 1986).

\section{DISGUSSION}

Type of substrate, hence geological source material, has been identified as an important requirement for surging and fast flow, because of its importance in overall bed roughness, subglacial hydrology and bed deformation potential. From the presence of many surging glaciers on severely deformed bedrock in fault-related areas, Post (1969) postulated that bed roughness or unusual bed permeability might be a controlling factor of glacier surging, but observed that surging glaciers in Alaska are not related to a single type of bedrock since surging occurs on sedimentary and volcanic as well as metamorphic rock. Comparison of surge probabilities in different drainage basins in the Yukon Territory with geology maps revealed no correlation of surge potential with lithology, geological age, regional tectonics, seismicity or physiographic boundaries (Clarke and others, 1986). However, surging appears strongly associated with the presence of fine-grained sedimentary substrates in Svalbard (Hamilton, 1992; Jiskoot and others, 2000). Furthermore, the global distribution of surge-type glaciers suggests that the majority of surging glaciers occur in young mountain ranges undergoing rapid erosion (Paterson, 1994), and the presence of many surging glaciers along the Denali fault in the Alaska Range suggests that surging might be connected to fault displacement and related deformation, and to the bedrock being friable (Post, 1969; Truffer and 
others, 1999). Conversely, the total absence of surging in many glaciated active fault areas and the surge clusters in regions without tectonic activity (e.g. the Yukon Territory (Clarke and others, 1986) and Svalbard (Hamilton, 1992; Jiskoot and others, 2000)) suggests that geological controls on surging are not evident.

What are the implied associations between geological conditions and surging in Greenland? Weidick (1988) suggested, on the basis of similarities in the basalt-dominated provinces in the central West and central East Greenland surge clusters, that geological conditions must exert a control on surging in Greenland. However, this study shows that surge-type glaciers within the East Greenland cluster overlie a variety of bedrock types and there is no statistically significant association between bedrock type and glacier surging in the optimal multivariate models. Although plateau basalts and sedimentary rocks, rather than hyaloclastite basalts and metamorphic rocks, are significantly related to surging in the univariate models, they are not significant when complexity is included. This would suggest a valley-shape control rather than a substrate control on surging in central East Greenland. However, curvature, another measure for valley-shape and positively correlated to complexity, is not significantly related to surging in any of the models. Valley shape and glacier complexity are likely important geologically controlled factors related to surge potential and need further investigation, but this is beyond the scope of this paper. Furthermore, neither geological boundary type, nor presence of a potentially deformable layer of Quaternary sediments at the margins, is significantly related to the distribution of surge-type glaciers in East Greenland. However, there are other geological signatures that are unrelated to the type of bedrock and that have recently been proposed to coincide with the onset locations of the fast-flowing portions of the Greenland ice sheet. These are places where the crust is thin and where geothermal heat is higher than average (Dahl-Jensen and others, 2001; Fahnestock and others, 2001). Indeed, if the distribution of active seismicity and tectonics on maps by Gregersen (1989) is compared to the distribution of surgetype glaciers in Greenland, then these regions seem to coincide remarkably well. Further research is needed to establish this proposed relation between fast-flow/surging behaviour and geologically active zones. Statistical research such as presented in this paper could help to establish the statistical significance of the correlation between the geographic distribution of surge-type glaciers and that of above-average geothermal heat flow.

What, apart from the geological setting, distinguishes surge-type glaciers in East Greenland from those in other areas? Using the same statistical analysis method as described in this paper, Jiskoot and others (2000) found that polythermal long glaciers with steep slopes, easterly aspects and overlying young sedimentary bedrock are most likely to be of surge type in Svalbard. In East Greenland, there is not only a lack of apparent geological control, but low slopes rather than steep slopes appear conducive to surging and there is no direct correlation between glacier length and surge potential. Hayes (2001) also found no specific substrate to relate to surge potential in Iceland or in the Yukon Territory and found that for Icelandic glaciers area rather than length is related to surge potential. Unique to our East Greenland surge-type glacier analysis is the inclusion of a measure for glacier complexity; hence the role of this has not been explored in other regions. The modelling results presented in this paper clearly show that the likelihood of surging increases with increasing complexity, and we interpret this as a valley-shape control on flow instability.

Comparing associations between surge-type glaciers and glacial and environmental characteristics in different regions suggests that different regions appear to have distinct controls on surging. This might in fact suggest that more than one surge mechanism may exist, so the controls already discovered may well be local. This finding might to some degree result from a lack of data in certain regions (e.g. "thermal regime" can only be inferred for a large number of glaciers where radio-echo sounding data are widely available such as in Svalbard). However, some characterictics of surge-type glaciers appear similar in different regions. The fact that geological boundaries appear not to be related to surging in any region suggests that a complex bed (e.g. an inhomogeneous substrate) is not a necessity for surging as is often hypothesized. Further, the predominantly easterly flow direction of surge-type glaciers in both East Greenland and Svalbard implies topographic effects on mass balance (e.g. shading, snow distribution, variation in insolation with aspect) are linked to surge potential, but further research is necessary to test this hypothesis.

Glacier dynamics studies have revealed that Svalbard surges are of long duration and relatively low speed compared to surges in Alaska and elsewhere (e.g. Dowdeswell and others, 1991). East Greenland surges tend to be more like Alaskan surges, being characterized by a short surge duration, rapid initiation and termination and high surge velocities (Murray and others, 2002) and have extreme subglacial water pressures during surges (Jiskoot and others, 2001). These observations suggest that there is more than one type of control on surging, and hence possibly more than one type of surge mechanism. This hypothesis is supported by the results in this paper, suggesting that associations between East Greenland surge-type glaciers and their environment and geometry are different than those found for other regions. For example, the apparent steep slopes found for surging glaciers in Svalbard (Jiskoot and others, 2000) and low slopes found for surging glaciers in East Greenland (this paper), in combination with the contrast in surge dynamics between the two regions, could be used to test if the linkedcavity surge mechanism as proposed by Kamb (1987) is viable in these regions. Kamb (1987) theorized that low slopes would distinguish surge-type from normal glaciers. From the results for low slopes of surge-type glaciers in East Greenland, as well as from glacier dynamics research on Sortebræ (Jiskoot and others, 2001; Murray and others, 2002), we propose a hydrologically controlled surge mechanism, possibly Kamb's linked-cavity surge mechanism, for East Greenland, rather than the thermally controlled surge mechanism postulated to operate in Svalbard.

\section{SUMMARY AND GONGLUSIONS}

In order to improve our understanding of the controls on surging, we have quantified the associations between environmental and glacial conditions and surging in a cluster region of surge-type glaciers in central East Greenland. The logistic modelling results presented in this study show that complex glaciers with relatively low slopes and oriented in a broad arc from northeast to south are most likely to surge. Further, glaciers overlying beds younger than Precam- 
brian and glaciers with high ELAs have increased surge potentials. Since surge-type glaciers in East Greenland are underlain by different substrates, and no single substrate or combination of these substrates was found to be significantly related to surge potential, it appears that simply character of substrate is not a control on surging in this region. The results for complexity in this research, namely, that surge potential increases with glacier complexity, suggest that valley shape could play an important role in the surge potential of glaciers.

\section{AGKNOWLEDGEMENTS}

We are grateful to A. Weidick, C. E. Bøggild, H. H. Thomsen and W. Starzer of the Geological Survey of Denmark and Greenland (GEUS), F. Bernth of the Danish Cadastral Survey (KMS) and H. Pritchard of the University of Leeds for access to data and assistance. KMS provided aerial photographs, and the European Space Agency ERS SAR data were distributed to us byVECTRA (University College London). We further thank the scientific editors C. F. Raymond and $\mathrm{H}$. Björnsson and two anonymous reviewers for useful suggestions on the manuscript. This research was possible through grants from the Royal Society, the U.K. Natural Environment Research Council (grant GST/02/2192) and the European Union's Leonardo da Vinci scheme.

\section{REFERENCES}

Clarke, G. K. C., J. P. Schmok, C. S. L. Ommanney and S. G. Collins. 1986. Characteristics of surge-type glaciers. 7. Geophys. Res., 91(B7), 7165-7180. Colvill, A. J. 1984. Some observations on glacier surges, with notes on the Roslin glacier, East Greenland. In Miller, K. J., ed. The International Karakoram Project. Proceedings of the International Conference. Vol. 1. Cambridge, Cambridge University Press, 64-75.

Dahl-Jensen, D., T. Dahl-Jensen and N. S. Gundestrup. 2001. Earthquakes and ice cores point to wet feet at the NorthGRIP deep drill site. [Abstract.] Eos, 82(47), Fall Meeting Supplement, F529.

Dowdeswell, J. A., G. S. Hamilton and J. O. Hagen. 1991. The duration of the active phase on surge-type glaciers: contrasts between Svalbard and other regions. 7. Glaciol., 37(127), 388-400.

Dwyer, J. L. 1995. Mapping tidewater glacier dynamics in East Greenland using Landsat data. F. Glaciol., 41(139), 584-595.

Fahnestock, M., W. Abdalati, I. Joughin, J. Brozena and P. Gogineni. 2001. High geothermal heat flow, basal melt, and the origin of rapid ice flow in central Greenland. Science, 294(5550), 2338-2342.

Gregersen, S. 1989. The seismicity of Greenland. In Gregersen, S. and P.W. Basham, eds. Earthquakes at North-Atlantic passive margins: neotectonics and postglacial rebound. Dordrecht, etc., Kluwer Academic Publishers, 345353. (NATO ASI Series C: Mathematical and Physical Sciences 266.
Hamilton, G. S. 1992. Investigations of surge-type glaciers in Svalbard. (Ph.D. thesis, University of Cambridge.)

Hayes, K. 2001. Controls on the incidence of glacier surging. (Ph.D. thesis, University of Leeds.)

Hendriksen, N. and S. Watts. 1968. Geological reconnaissance of the Scorsby Sund Fjord complex. Grønl. Geol. Undersøgelse, Rapp. 15, 72-77.

Jiskoot, H., P. Boyle and T. Murray. 1998. The incidence of glacier surging in Svalbard: evidence from multivariate statistics. Comput. Geosci., 24(4), 387-399.

Jiskoot, H., T. Murray and P. Boyle. 2000. Controls on the distribution of surge-type glaciers in Svalbard. F. Glaciol., 46(154), 412-422.

Jiskoot, H., A. K. Pedersen and T. Murray. 2001. Multi-model photogrammetric analysis of the 1990s surge of Sortebræ, East Greenland. F. Glaciol., 47(159), 677-687.

Kamb, B. 1987. Glacier surge mechanism based on linked cavity configuration of the basal water conduit system. F. Geophys. Res., 92(B9), 9083-9100.

Kamb, B. and 7 others. 1985. Glacier surge mechanism: 1982-1983 surge of Variegated Glacier, Alaska. Science, 227(4686), 469-479.

Luckman, A., T. Murray, H. Jiskoot, H. Pritchard and T. Strozzi. 2003. ERS SAR feature-tracking measurement of outlet glacier velocities on a regional scale in East Greenland. Ann. Glaciol., 36 (see paper in this volume).

Murray, T. and 6 others. 2000. Glacier surge propagation by thermal evolution at the bed. F. Geophys. Res., 105(B6), 13,491-13,507.

Murray, T., T. Strozzi, A. Luckman, H. Pritchard and H. Jiskoot. 2002. Ice dynamics during a surge of Sortebræ, East Greenland. Ann. Glaciol., 34, 323-329.

Murray, T., A. Luckman, T. Strozzi and A.-M. Nuttall. 2003. The initiation of glacier surging at Fridtjovbreen, Svalbard. Ann. Glaciol., 36 (see paper in this volume).

Nuttall, A.-M. 1993. Glaciological investigations in East Greenland using digital Landsat imagery. (M.Phil thesis, University of Cambridge.)

Paterson, W. S. B. 1994. The physics of glaciers. Thirdedition. Oxford, etc., Elsevier.

Post, A. 1969. Distribution of surging glaciers in western North America. F. Glaciol., 8(53), 229-240.

Rucklidge, J. 1966. Observation of hollows in the snow surface of Torv Gletscher, East Greenland. F. Glaciol., 6(45), 446-449.

Rutishauser, H. 1971. Observations on a surging glacier in East Greenland. f. Glaciol., 10(59), 227-236.

Thomsen, T. and A. Weidick. 1993. Climate change impacts on northern water resources in Greenland. In Prowse, T. D., C. S. L. Ommanney and K. E. Ulmer, eds. Proceedings of the 9th International Northern Research Basins Symposium/Workshop, 14-22 August 1992: Whitehorse, Dawson City, Eagle Plains, Tukon; Inuvik, Northwest Territories. Vol. 2. Saskatoon, Saskatchewan, National Hydrology Research Institute, Environment Canada, 749-781. (NHRI Symposium No. 10.)

Truffer, M., R. J. Motyka, W. D. Harrison, K. A. Echelmeyer, B. Fisk and S. Tulaczyk. 1999. Subglacial drilling at Black Rapids Glacier, Alaska, U.S.A.: drilling method and sample descriptions. F. Glaciol., 45(151), 495-505.

Weidick, A. 1988. Surging glaciers in Greenland: a status. Gronl. Geol. Undersøgelse, Rapp. 140, 106-110.

Weidick, A. 2001. Neoglacial glaciations around Hans Tausen Iskappe, Peary Land, North Greenland. Medd. Gronl., Geoscience 39, 5-26.

Weidick, A., C. E. Bøggild and N.T. Knudsen. 1992. Glacier inventory and atlas of West Greenland. Gronl. Geol. Undersogelse, Rapp. 158. 